\title{
Analysis of Lut Tawar Health Center Service Quality on Outpatient Patient Satisfaction in Central Aceh Regency
}

\author{
Asriwati Amirah $^{1}$, Mappeaty Nyorong ${ }^{1}$, Wahyu Fatrah Nananda ${ }^{2}$ \\ ${ }^{1}$ Faculty of Public Health Helvetia Institute of Health Medan, Indonesia \\ ${ }^{2}$ Student of Master Program in Public Health, Helvetia Institute of Health Medan, \\ Indonesia
}

\begin{abstract}
The purpose of this study was to find out what aspects were related to the quality of service at the Lut Tawar Health Center to the Satisfaction of Outpatients in Central Aceh Regency. The research design used in this study was Cross Sectional. The population in this study was 7,507 people and the samples taken by accidental sampling were 99 people. Data collection methods are primary data and secondary data. Analysis of the data used is a binary logistic regression test. The results showed that the physical condition had a sig-p value of $0.004<0.05$, reliability sig-p $0.004<0.005$, and a sig-p guarantee of $0.030<0.05$, which means that it has a relationship with the quality of health services, while responsiveness has no relationship to the quality of health services because it has a sig-p value of $0.173>0.05$ and concern has no relationship to the quality of health services because it has a sig-p value of $0.893>0.05$. The most dominant aspect related to service quality is the variable of physical condition $p=0.004$ $<0.05$. The conclusion in this study is that there is a relationship between physical condition, reliability, and assurance on the quality of Community Health Center (puskesmas) services, while the responsiveness and caring variables have no relationship to the quality of puskesmas services.
\end{abstract}

Keywords: Quality of Service, Community Health Center, Outpatients

Received : October 17, 2021

Received in Revised: November 25, 2021

Accepted: December 4, 2021

\section{Introduction}

Health efforts are carried out in the form of activities with promotive, curative and rehabilitative approaches that are carried out in an integrated, comprehensive and sustainable manner. Puskesmas is the spearhead of the implementation of health services in an area in Indonesia and is a comprehensive and integrated organization that is closest to the community. Community services include efforts to improve, prevent, and cure. The role and function of Puskesmas is very strategic in health development in Indonesia. The role of Puskesmas is to organize health efforts to increase awareness, willingness, and ability to live healthy for every resident in order to obtain optimal health status (Saputro, 2015).

The quality of health services is an indispensable requirement in every country, not only developed countries but developing countries also prioritize health services, in fact the services provided to patients in developing countries such as Malaysia, Thailand, Singapore and Brunei satisfy their patients (Supranto, 2001). This can be seen from the coverage of health services in health facilities with a target of $75 \%$, but $80 \%$ of patients who say they are satisfied with the services provided. 
It is evident that Malaysia and Singapore are the main destinations for Indonesian people's treatment. Likewise America, Japan, Britain and France developed countries that have health services that provide satisfaction to patients with a percentage of $82,7 \%$ (WHO, 2013).

Quality health services are health services that must pay attention to four main elements. The four main elements are elements of input (input), environment (environment), process (process), and output (output). To maintain the quality of health services, many efforts can be made. These efforts, if carried out in a directed and planned manner, are called quality maintenance programs. The quality maintenance program is a continuous, systematic and objective effort in monitoring and assessing the services provided compared to the established standards, as well as resolving problems found to improve service quality (Kemenkes, 2013).

Factors that influence patient satisfaction related to health care services include satisfaction with service access, satisfaction with service quality, satisfaction with the health service process and satisfaction with the health care system (Soejadi, 2010).

Efforts to improve the quality of health services are increasingly getting attention, because efforts to improve the quality of health services involve various comprehensive aspects, both in medical, non-medical services and facilities. This will increase the effectiveness and efficiency of the health service itself. Health services at the Puskesmas face challenges, including meeting community expectations for the quality of health services and the capacity of Puskesmas services. This is due to various factors that drive the importance of the quality of Puskesmas services, including the development of science and technology, especially in the medical field which can result in more expensive service costs, limited health center resources so that efforts are needed to make services more effective and efficient, with active regulations, standardization of service standards, demands from third parties (insurance), increased professional responsibilities, as well as increasing education and social economy of the community (Azwar, 1996).

Lut Tawar Health Center as a first-level health service facility in the work area of Central Aceh Regency which has been accredited middle, this health center organizes public health efforts and individual health efforts. Puskesmas carry out health efforts by prioritizing promotive and preventive efforts. Health efforts at the Lut Tawar Health Center are divided into mandatory health efforts and development health efforts.

Patient complaints are due to the fact that the services provided are not on time when needed, doctors are rarely available, communication made by health workers is not good and clear, and service support facilities from the Puskesmas are inadequate. This is what causes patients who visit the Lut Tawar Health Center, Central Aceh Regency not to be satisfied with the services provided by health workers at the Puskesmas

\section{Methods}

This study uses a Cross Sectional approach, which is to study the relationship between risk factors and events by using observation or data collection methods at the same time (Muhammad, 2015). The population in this study were all outpatients at the Lut Tawar Health Center during August 2021 consisting of 7507 patients. The sampling technique in this study was accidental sampling, namely sampling based on the fact that they happened to appear at the time of conducting research using the Slovin formula as many as 99 patients 


\section{Results and Discussion}

\section{Respondent's Characteristics}

Based on the research results of age, gender, education, occupation can be seen in the following table:

Table 1. Distribution of Age, Gender, Education, Occupation of Outpatients at Lut Tawar Health Center, Central Aceh Regency $(n=99)$

\begin{tabular}{|c|l|c|c|}
\hline No & Age & Frequency (f) & Percentage (\%) \\
\hline 1 & $>61$ years & 8 & 8.1 \\
\hline 2 & $51-61$ Years & 17 & 17.2 \\
\hline 3 & $40-50$ Years & 31 & 31.3 \\
\hline 4 & 29-39 Years & 30 & 30.3 \\
\hline 5 & $18-28$ Years & 13 & 13.1 \\
\hline No & Gender & Frequency (f) & Percentage (\%) \\
\hline 1 & Woman & 53 & 53.5 \\
\hline 2 & Man & Frequency (f) & Percentage (\%) \\
\hline No & Education & 8 & 8.1 \\
\hline 1 & Not school & 17 & 17.2 \\
\hline 2 & Elementary School & 24 & 24.2 \\
\hline 3 & Junior School & 34 & 34.3 \\
\hline 4 & High School & 16 & 16.2 \\
\hline 5 & College & Frequency (f) & Percentage (\%) \\
\hline No & Work & 27 & 27.3 \\
\hline 1 & Not Working & 31 & 31.3 \\
\hline 2 & Self employed & 29 & 29.3 \\
\hline 3 & Farmer & 12 & 12.1 \\
\hline 4 & Civil Servant & $\mathbf{9 9}$ & $\mathbf{1 0 0}$ \\
\hline & Total & &
\end{tabular}

Table 1 shows that of the 99 respondents studied, the majority of respondents in the category $40-50$ years old were 31 people $(31.3 \%)$ and the minority in the category $>61$ years old were 8 people $(8.1 \%) .53$ women $(53.5 \%)$ and male minorities $46(46.5 \%)$, the majority of high school education as many as 34 people (34.3\%) and the minority who did not go to school as many as 8 people $(8,1 \%)$, while the majority of occupations are self-employed as many as 31 people $(31.3 \%)$ while the minority are civil servants as many as 12 people $(12.1 \%)$.

\section{Patient's Satisfaction}

Table 2. Distribution of Outpatient Satisfaction at Lut Tawar Health Center, Central Aceh Regency ( $\mathrm{n}=99)$

\begin{tabular}{|c|l|c|c|}
\hline No & Physical State (Tangibles) & $\mathbf{f}$ & $\mathbf{\%}$ \\
\hline 1 & Not satisfied & 54 & 54.5 \\
\hline 2 & Satisfied & 45 & 45.5 \\
\hline & Total & $\mathbf{9 9}$ & $\mathbf{1 0 0}$ \\
\hline No & Reliability & $\mathbf{f}$ & $\mathbf{\%}$ \\
\hline 1 & Not satisfied & 50 & 50.5 \\
\hline 2 & Satisfied & 49 & 49.5 \\
\hline
\end{tabular}




\begin{tabular}{|c|l|c|c|}
\hline & Total & $\mathbf{9 9}$ & $\mathbf{1 0 0}$ \\
\hline No & Responsiveness & $\mathbf{f}$ & $\mathbf{\%}$ \\
\hline 1 & Not satisfied & 53 & 53.5 \\
\hline 2 & Satisfied & 46 & 46.5 \\
\hline & Total & $\mathbf{9 9}$ & $\mathbf{1 0 0}$ \\
\hline No & Guarantee (Assurance) & $\mathbf{f}$ & $\mathbf{\%}$ \\
\hline 1 & Not satisfied & 48 & 48.5 \\
\hline 2 & Satisfied & 51 & 51.5 \\
\hline & Total & $\mathbf{9 9}$ & $\mathbf{1 0 0}$ \\
\hline No & Caring (Empathy) & $\mathbf{f}$ & $\mathbf{\%}$ \\
\hline 1 & Not satisfied & 48 & 48.5 \\
\hline 2 & Satisfied & 51 & 51.5 \\
\hline & Total & $\mathbf{9 9}$ & $\mathbf{1 0 0}$ \\
\hline
\end{tabular}

Table 2 shows that of the 99 respondents studied, the majority with Physical Conditions (tangibles) Dissatisfied as many as 54 people (54.5\%) and the minority with Physical Conditions (tangibles) Satisfied as many as 45 people (45.5\%). The majority with Reliability (reliability) Dissatisfied as many as 50 people $(50.5 \%)$ and the minority with Reliability (reliability) Satisfied as many as 49 people (49.5\%). The majority with Responsiveness (responsiveness) Dissatisfied as many as 53 people (53.5\%) and the minority Responsiveness (responsiveness) Satisfied as many as 46 people (46.5\%). The majority with Satisfied Assurance as many as 51 people (51.5\%) and the minority with Dissatisfied Assurance as many as 48 people (48.5\%). The majority with Caring (empathy) Satisfied as many as 51 people $(51.5 \%)$ and the minority Caring (empathy) Dissatisfied as many as 48 people $(48.5 \%)$.

\section{Service Quality}

Table 3. Distribution of Quality of Outpatient Services at Lut Tawar Health Center, Central Aceh Regency $(n=99)$

\begin{tabular}{|l|l|c|c|}
\hline No & Quality of Service & f & \% \\
\hline 1 & Bad & 61 & 61,6 \\
\hline 2 & Good & 38 & 38,4 \\
\hline & Total & $\mathbf{9 9}$ & $\mathbf{1 0 0}$ \\
\hline
\end{tabular}

Table 3. shows that of the 99 respondents studied, the majority with Poor Service Quality as many as 61 people $(61.6 .5 \%)$ and the minority with Good Service Quality as many as 38 people $(38.4 \%)$.

\section{Bivariate Analysis}

After the univariate analysis of the results of the study was carried out with bivariate analysis, namely by using the Chi-Square test, the relationship between the independent variable and the dependent variable with the statistical significance limit of $\mathrm{p}$-value (0.05), the following results were obtained:

The results of the study with cross tabulation of physical condition on service quality can be seen in table 4 below:

Table 4. Relationship of Physical Conditions (Tangibles) with Quality of Service at Lut Tawar Health Center on Outpatient Satisfaction in Central Aceh Regency ( $\mathrm{n}=99)$

\begin{tabular}{|c|c|c|c|}
\hline Quality of Service & Physical State (Tangibles) & Total & Value \\
\hline
\end{tabular}

Copyright @ 2021, International Journal Papier Advance and Scientific Review, Under the license CC BY-SA 4.0

DOI: https://doi.org/10.47667/ijpasr.v2i2.122 


\begin{tabular}{|c|c|c|c|c|c|c|c|}
\hline & \multicolumn{2}{|c|}{ Not satisfied } & \multicolumn{2}{c|}{ Satisfied } & \multicolumn{2}{|c|}{} & $\boldsymbol{p}$ \\
\cline { 2 - 8 } & $\mathbf{F}$ & $\mathbf{\%}$ & $\mathbf{f}$ & $\mathbf{\%}$ & $\mathbf{f}$ & $\mathbf{\%}$ & \\
\hline Bad & 52 & 85,2 & 9 & 14,8 & 61 & 100 & 0,000 \\
Good & 2 & 5,3 & 36 & 94,7 & 38 & 100 & \\
\hline Total & $\mathbf{5 4}$ & $\mathbf{5 4 , 5}$ & $\mathbf{4 5}$ & $\mathbf{4 5 , 5}$ & $\mathbf{9 9}$ & $\mathbf{1 0 0}$ & \\
\hline
\end{tabular}

Based on table 4. it can be seen that the quality of service is not good as many as 52 people $(85.2 \%)$ with the category of physical condition (tangibles) are not satisfied while the quality of service is not good as many as 9 people $(14.8 \%)$ with the category of physical condition (tangibles). satisfied. Good service quality as many as 2 people $(5.3 \%)$ have a physical condition category (tangibles) are not satisfied while the quality of good service as many as 36 people $(5.3 \%)$ have a physical condition category (tangibles) are satisfied.

The results of the Chi-Square analysis in the attachment of the Continuity Correction test table between the relationship between physical conditions (tangibles) and service quality are known that the probability value $(0.000)<=0.05$, so it can be concluded that physical conditions (tangibles) have a significant influence on quality. outpatient service at the Lut Tawar Health Center, Central Aceh Regency.

The results of the research with cross tabulation of reliability on service quality can be seen in table 4.5 below:

Table 5. Relationship between Reliability and Quality of Outpatient Services in Central Aceh $(n=99)$

\begin{tabular}{|c|c|c|c|c|c|c|c|}
\hline \multirow[t]{3}{*}{ Quality of Service } & \multicolumn{4}{|c|}{ Reliability(reliability) } & \multirow{2}{*}{\multicolumn{2}{|c|}{ Total }} & \multirow{2}{*}{$\begin{array}{c}\text { Value } \\
\boldsymbol{p} \\
\end{array}$} \\
\hline & \multicolumn{2}{|c|}{ Not satisfied } & \multicolumn{2}{|c|}{ Satisfied } & & & \\
\hline & $\mathbf{F}$ & $\%$ & $\mathbf{F}$ & $\%$ & $\mathbf{f}$ & $\%$ & \\
\hline $\mathrm{Bad}$ & 49 & 80,3 & 12 & 19,7 & 61 & 100 & 0,000 \\
\hline Good & 1 & 2,6 & 37 & 97,4 & 38 & 100 & \\
\hline Total & 50 & 50,5 & 49 & 49,5 & 99 & 100 & \\
\hline
\end{tabular}

Based on table 5. it can be seen that the quality of service is not good as many as 49 people $(80.3 \%)$ with the category of reliability (reliability) are not satisfied while the quality of service is not good as many as 12 people $(19.7 \%)$ with the category of reliability (reliability) satisfied. Good service quality as many as 1 person (2.6\%) has the category of reliability (reliability) is not satisfied while the quality of good service as many as 37 people $(97.4 \%)$ have the category of reliability (reliability) satisfied.

The results of the Chi-Square analysis in the attachment of the Continuity Correction test table between the relationship between reliability and service quality, it is known that the probability value $(0.000)<=0.000$ so it can be concluded that reliability has a significant influence on the quality of outpatient services at the Lut Tawar Health Center. Central Aceh District.

The results of the research by cross tabulating responsiveness to service quality can be seen in table 6 below:

Table 6. The Relationship of Responsiveness to the Quality of Outpatient Service at the Lut Tawar Public Health Center, Central Aceh ( $n=99)$

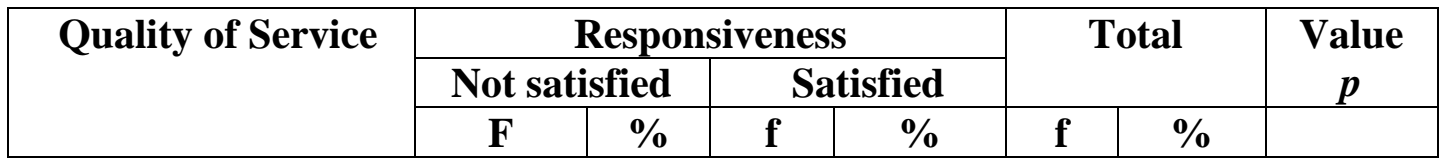




\begin{tabular}{|c|c|c|c|c|c|c|c|}
\hline Bad & 48 & 78,7 & 13 & 21,3 & 61 & 100 & 0,000 \\
Good & 5 & 13,2 & 33 & 86,8 & 38 & 100 & \\
\hline Total & $\mathbf{5 3}$ & $\mathbf{5 3 , 5}$ & $\mathbf{4 6}$ & $\mathbf{4 6 , 5}$ & $\mathbf{9 9}$ & $\mathbf{1 0 0}$ & \\
\hline
\end{tabular}

Based on table 6. it can be seen that the quality of service is not good as many as 48 people $(78.7 \%)$ in the category of poor responsiveness while the quality of service is not good as many as 13 people $(21.3 \%)$ in the category of good responsiveness. Good service quality as many as 5 people (13.2\%) have a bad response category while good service quality as many as 33 people $(86.8 \%)$ have a good responsiveness category.

The results of the Chi-Square analysis in the attachment of the Continuity Correction test table between the responsiveness relationship to service quality, it is known that the probability value $(0.000)<=0.05$, so it can be concluded that responsiveness has a significant influence on the quality of outpatient services at the Lut Tawar Health Center. Central Aceh District.

The results of the research with cross tabulation of concern (empathy) on service quality can be seen in table 4.7 below:

Table 7. The Relationship of Concern (empathy) to the Quality of Outpatient Services at the Kebayakan Health Center, Central Aceh $(n=99)$

\begin{tabular}{|c|c|c|c|c|c|c|c|}
\hline \multirow[t]{3}{*}{ Quality of Service } & \multicolumn{4}{|c|}{ Caring (empathy) } & \multirow{2}{*}{\multicolumn{2}{|c|}{ Total }} & \multirow{2}{*}{$\begin{array}{c}\text { Value } \\
p\end{array}$} \\
\hline & \multicolumn{2}{|c|}{ Not satisfied } & \multicolumn{2}{|c|}{ Satisfied } & & & \\
\hline & $\mathbf{F}$ & $\%$ & $\mathbf{f}$ & $\%$ & $\mathbf{f}$ & $\%$ & \\
\hline $\mathrm{Bad}$ & 42 & 68,9 & 19 & 31,1 & 61 & 100 & 0,000 \\
\hline Good & 5 & 13,2 & 33 & 86,8 & 38 & 100 & \\
\hline Total & 47 & 47,5 & 52 & 52,5 & 99 & 100 & \\
\hline
\end{tabular}

Based on table 7, it can be seen that the quality of service is not good as many as 42 people $(68.9 \%)$ with the category of caring (empathy) being dissatisfied while the quality of service is not good as many as 19 people (31.1\%) with the category of caring (empathy) being satisfied. Good service quality as many as 5 people $(13.2 \%)$ have a category of caring (empathy) are not satisfied while the quality of good service as many as 33 people $(86.8 \%)$ have a category of concern (empathy) are satisfied.

The results of the Chi-Square analysis in the attachment of the Continuity Correction test table between the relationship of concern (empathy) to service quality, it is known that the probability value $(0.000)<=0.05$, so it can be concluded that caring (empathy) has a significant influence on service quality. outpatients at the Lut Tawar Health Center, Central Aceh Regency.

The results of the research with cross tabulation of assurance on service quality can be seen in table 8 below:

Table 8. Relationship of Assurance to the Quality of Outpatient Services at Lut Tawar Public Health Center, Central Aceh Regency $(n=99)$

\begin{tabular}{|c|c|c|c|c|c|c|c|}
\hline \multirow[t]{3}{*}{ Quality of Service } & \multicolumn{4}{|c|}{ Guarantee (assurance) } & \multirow{2}{*}{\multicolumn{2}{|c|}{ Total }} & \multirow{3}{*}{$\begin{array}{c}\text { Value } \\
p\end{array}$} \\
\hline & \multicolumn{2}{|c|}{ Not satisfied } & \multicolumn{2}{|c|}{ Satisfied } & & & \\
\hline & $\mathbf{F}$ & $\%$ & $\mathbf{f}$ & $\%$ & $\mathbf{f}$ & $\%$ & \\
\hline $\mathrm{Bad}$ & 45 & 73,8 & 16 & 26,2 & 61 & 100 & 0,000 \\
\hline Good & 3 & 7,9 & 35 & 92,1 & 38 & 100 & \\
\hline Total & 48 & 48,5 & 51 & 51,5 & 99 & 100 & \\
\hline
\end{tabular}


Based on table 4.8, it can be seen that the quality of service is not good as many as 45 people $(73.8 \%)$ with the category of assurance (assurance) are not satisfied while the quality of service is not good as many as 16 people (26.2\%) with the category of assurance (assurance) satisfied. Good service quality as many as 3 people $(7.9 \%)$ have the category of assurance (assurance) are not satisfied while the quality of good service as many as 35 people $(92.1 \%)$ have the category of assurance (assurance) are satisfied.

The results of the Chi-Square analysis in the attachment of the Continuity Correction test table between the assurance relationship and service quality, it is known that the probability value $(0.000)<=0.05$, so it can be concluded that assurance has a significant influence on service quality. outpatients at the Lut Tawar Health Center, Central Aceh Regency.

\section{Multivariate Analysis}

The results of the multivariate analysis test with logistic regression test are in accordance with the following table:

\section{Stage 1 (Enter Method)}

Table 9. Results of the Logistics Regression Test Analysis of the Service Quality of the Lut Tawar Health Center for Outpatients in Central Aceh Regency

\begin{tabular}{|c|c|c|c|c|c|c|c|c|}
\hline No & Variable & B & S.E. & Forest & df & Sing & $\mathbf{E x p ( B )}$ & $\mathbf{9 5 \% \text { CI }}$ \\
\hline 1 & $\begin{array}{c}\text { Physical } \\
\text { State(tangibles) }\end{array}$ & 3,425 & 1,200 & 8,151 & 1 & 0,004 & 30,728 & $\begin{array}{c}2,926- \\
322,661\end{array}$ \\
\hline 2 & $\begin{array}{c}\text { Reliability(relia } \\
\text { bility) }\end{array}$ & 3,714 & 1,372 & 7,328 & 1 & 0,007 & 41,019 & $\begin{array}{c}2,782- \\
603,668\end{array}$ \\
\hline 3 & $\begin{array}{c}\text { Responsiveness } \\
4\end{array}$ & 1,798 & 1,319 & 1,858 & 1 & 0,173 & 6,037 & $\begin{array}{c}0,455- \\
80,108\end{array}$ \\
\hline 5 & $\begin{array}{c}\text { Guarantee(assur } \\
\text { ance) }\end{array}$ & 2,478 & 1,147 & 4,672 & 1 & 0,031 & 11,920 & $\begin{array}{c}1,260- \\
112,769\end{array}$ \\
\hline
\end{tabular}

\section{Stage 2 (Backward Stepwise Method)}

Based on the logistic regression test, stage 2 (Backward Stepwise Method (Conditional) to determine the dominant influence of the independent variable with the dependent variable having a value of $\mathrm{p}=<0.05$, namely physical condition, reliability, assurance.

Table 10. Results of the Logistics Regression Test Analysis of the Service Quality of the Lut Tawar Health Center for Outpatients in Central Aceh Regency

\begin{tabular}{|c|c|c|c|c|c|c|c|c|}
\hline No & Variable & B & S.E. & Forest & Df & Sing & $\mathbf{E x p ( B )}$ & 95\% CI \\
\hline 1 & $\begin{array}{c}\text { Physical } \\
\text { State(tangibles) }\end{array}$ & 3,428 & 1,197 & 8,206 & 1 & 0,004 & 30,819 & $\begin{array}{c}2,952- \\
321,714\end{array}$ \\
\hline 2 & $\begin{array}{c}\text { Reliability(relia } \\
\text { bility) }\end{array}$ & 3,771 & 1,308 & 8,309 & 1 & 0,004 & 43,441 & $\begin{array}{c}3,343- \\
563,746\end{array}$ \\
\hline 3 & $\begin{array}{c}\text { Guarantee(assur } \\
\text { ance) }\end{array}$ & 2,472 & 1,140 & 4,704 & 1 & 0,030 & 11,849 & $\begin{array}{c}1,269- \\
110,643\end{array}$ \\
\hline
\end{tabular}

Based on the results from table 4.10. From the results above, the most dominant aspect that affects the service quality of the Lut Tawar health center is the variable physical condition (tangibles) $\mathrm{p}=0.004<0.05$ and $95 \% \mathrm{CI}=2.952-3.343$ meaning that physical conditions

Copyright $@$ ( 2021, International Journal Papier Advance and Scientific Review, Under the license CC BY-SA 4.0

DOI: https://doi.org/10.47667/ijpasr.v2i2.122 
(tangibles) affect the service quality of the Lut Tawar health center. bargaining with outpatients in Central Aceh Regency.

The physical condition variable (tangibles) has a sig-p value of $0.004<0.05$, meaning that the physical condition is significantly related to the Quality of Service of the Lut Tawar Health Center on Outpatient Patient Satisfaction in Central Aceh Regency. This shows that some respondents stated that the Puskesmas building was still not clean, the waiting chairs available in the puskesmas area were still lacking and adequate, the patient waiting room was available in the puskesmas area there was still garbage or not clean, the bathroom still smelled and was not clean. and the Puskesmas room is still not neatly arranged.

The reliability variable has a sig-p value of $0.004<0.05$, meaning that reliability has a significant influence on the quality of services at the Lut Tawar Health Center on Outpatient Patient Satisfaction in Central Aceh Regency. The reliability of nursing care that needs to be increased at the Puskesmas based on the results of the description of the respondents' answers in this study is the procedure for receiving patients to be served quickly and precisely without being complicated and the readiness of health workers to serve patients at any time. Reliability or service reliability will be provided if it can be trusted by customers including services that must be consistent, in addition to convoluted services and the length of the patient's waiting period can determine the quality of health services because it makes patients feel that they are not being served properly so that this can lead to dissatisfaction.

The assurance variable has a sig-p value of $0.030<0.05$, meaning that assurance has a significant relationship to the Quality of Service of the Lut Tawar Health Center on Outpatient Patient Satisfaction in Central Aceh Regency. Health centers need to improve the education of health workers in the form of training, workshops and the ability of health workers to serve patients because the education and skills of health workers are very guaranteed in helping the healing process of patients, this greatly affects the trust of patients so that later patients feel safe in obtaining care services from officers health.

\section{Conclusion}

It is hoped that the Puskesmas will keep the Puskesmas environment clean and tidy, maintain the tidiness of health workers, increase the number of waiting chairs for visiting patients, provide sufficient trash cans, always maintain the cleanliness of the toilets and take care of the beauty of the Puskesmas buildings. Health workers can provide services to patients quickly and precisely, not letting patients wait too long to get treatment and give medicine to patients according to their illness.

\section{References}

Azwar, A. (1996). Menjaga mutu pelayanan kesehatan. Jakarta: pustaka sinar harapan, 1496

Kemenkes RI. (2013). Buku Pegangan Sosialisasi Jaminan Kesehatan Nasional (JKN) dalam Sistem Jaminan Sosial Nasional. Clim Chang 2013 - Phys Sci Basis. 2013

Muhammad I. (2015). Panduan penyusunan Karya Tulis Ilmiah Bidang Kesehatan Menggunakan Metode Ilmiah. Bandung: Cita Pustaka Media Perintis.

Saputro, A. D. (2015). Hubungan Kualitas Pelayanan Kesehatan dengan Kepuasan Pasien Rawat Jalan Tanggungan BPJS Dirumah Sakit Bethesda Yogyakarta (Doctoral dissertation, Universitas Muhammadiyah Surakarta)

Soejadi. (2010). Pedoman Penilaian Kinerja Rumah Sakit. Jakarta: Kartika Bina 
Supranto, J. (2001). Pengukuran tingkat kepuasan pelanggan. repo.unikadelasalle.ac.id

WHO. (2013). World Helath Organization. The world health report 2013. Researchfor universal health coverage. World Heal Organ Press. 